\title{
TERMINATION OF EARLY PREGNANCY IN RATS AFTER OVARIECTOMY IS DUE TO IMMEDIATE COLLAPSE OF THE PROGESTERONE- DEPENDENT DECIDUA
}

\author{
RUTH DEANESLY \\ A.R.C. Institute of Animal Physiology, Babraham, Cambridge
}

(Received 22nd May 1973)

In guinea-pigs ovariectomized before implantation, where conceptuses continue to develop for some days, partial and finally complete haemorrhagic degeneration of the decidua takes place, usually terminating pregnancy by Day 16 or earlier. This can be prevented by exogenous progesterone (Deanesly, 1972). In pregnant rats, termination of pregnancy following ovariectomy is well known, but its immediate effect on the conceptuses does not appear to have been described. To compare their reactions with those in the guinea-pig, 6- to 9-day pregnant rats (vaginal plug, Day 0) were ovariectomized under ether anaesthesia and killed up to 2 days later, or after a longer interval if given progesterone. The 6- to 12-day conceptuses, fixed in Bouin's fluid and weighed from $70 \%$ alcohol, were compared with those from normal animals at corresponding ages. All were sectioned serially in the sagittal plane at $7 \mu \mathrm{m}$, and stained with haematoxylin and eosin. When progesterone was given, the rats received daily subcutaneous injections in oil $(10 \mathrm{mg} / \mathrm{ml})$, the first at the time of ovariectomy. Almost all animals were killed 1 day after the last injection.

The development and histochemistry of the rat decidua from the 5th day has been described by Krehbiel (1937), Bridgman (1948) and Christie (1967). All these writers refer to the probable rôle of decidual glycogen in the nutrition of the early embryo. By the 6th day, the embryo is beginning to implant antimesometrially and by the 7th day (Pl. 1, Fig. 1), decidual tissue blocks the uterine lumen. Up to Day 9 to 10, it occupies most of the conceptus. In the antimesometrial decidua, the cells are large and often binucleate but in the mesometrial decidua, they are smaller and more densely packed. Both areas show cell division. The lateral areas between, bordering on the uterine lumen, are not yet distinguishable as such.

At 8 to 9 days, a fibrous boundary to the antimesometrial decidua has formed and the lateral areas are becoming vacuolated. By the 10th day in the expanded conceptus, a new lumen is opening and breaking through the fibrous capsule antimesometrially; the decidua contracts to the decidua capsularis (Pl. 1 and 2, Figs 4 and 7). There are still a few mitotic figures near its exterior but, further in, decidual nuclei have ceased to be vesicular or to divide. In the lateral areas, there is vacuolation and degeneration, but the mesometrial decidua is intact.

Preliminary experiments, in which seven 6- and 7-day pregnant rats were 
killed up to $25 \mathrm{hr}$ after ovariectomy, showed that in two the conceptuses were unaffected after 11 and $17 \mathrm{hr}$, while, in two others, there was an early reaction. The embryo appeared healthy and most of the decidua was still intact, but the lateral areas were markedly congested and the decidual cells shrunken and tapering; cell degeneration at the exterior had attracted numerous polymorphs (Pl. 1, Fig. 2). In the remaining three rats and in two ovariectomized at 8 and 9 days and killed a day later, conceptuses had lost shape and pregnancy had broken down completely. Most of the decidua had degenerated and become haemorrhagic. Extravasated blood and the remnants of decidual tissue had already in some cases passed into the uterine lumen with the embryo (cf. Pl. 2, Fig. 6).

The immediate and most conspicuous effect of ovariectomy in these 6- to 9-day rats was the degeneration of the decidua leading to haemorrhagic collapse of the whole conceptus. Since progesterone can maintain pregnancy in the postimplantation ovariectomized rat (Rothchild \& Meyer, 1940, and others), it can be assumed that decidual degeneration is a direct result of progesterone deficiency. At 6 days, when the decidua was growing actively, the reaction to ovariectomy was less rapid than in later stages, when total degeneration of the decidua with termination of pregnancy could occur in less than $24 \mathrm{hr}$.

In a further series of experiments, various amounts of progesterone were given to twenty-five ovariectomized rats to provide histological material showing maintenance or degeneration of the decidua and the corresponding pregnancy, together with intermediate degenerating stages. The latter were comparatively rare, indicating the rapidity of the degenerative process.

After ovariectomy on Day 6 or 7, an injection of 1,2 or $4 \mathrm{mg}$ progesterone daily sufficed to maintain the conceptuses for 1 or 2 days in six rats but, from Day 8 , an injection of 3 to $5 \mathrm{mg}$ might be necessary to ensure growth and differentiation. Average weights of the conceptuses in experimental rats were almost always a little below those of the corresponding controls. Congestion of the lateral areas of the decidua could be seen in a rat ovariectomized on Day 8, given $2 \mathrm{mg}$ progesterone and killed 1 day later (Pl. 1, Fig. 3). In sections, mitotic figures could still be seen in both the decidua and the embryo, but

\section{EXPLANATION OF PLATES}

Sagittal sections through 7- to 10-day rat conceptuses; antimesometrial decidua uppermost. Abbreviations: d.c., decidua capsularis; m.d. mesometrial decidua; lu, lumen; plac. placenta

\section{PLATE 1}

FIG. 1. No. 12. Normal 7-day conceptus. $\times 21$.

FIG. 2. No. 11. Part of a conceptus, which has lost shape, from a rat ovariectomized on Day 6 and killed on Day 7; the section shows cell shrinkage, congestion and degeneration in the lateral areas of the decidua. $\times 50$.

Fig. 3. No. 25. Conceptus from rat ovariectomized on Day 8, given $2 \mathrm{mg}$ progesterone and killed on Day 9. Progesterone deficiency again shown by conspicuous congestion of the lateral decidual areas. $\times 21$.

FIG. 4. No. 7. Conceptus from a rat ovariectomized on Day 8 , given $2 \mathrm{mg}$ progesterone on Days 8 and 9 and killed on Day 10 . The partially maintained conceptus resembles the 10-day normal one with early placental development (see Pl. 2, Fig. 7), but it is smaller. The decidua has shrunk and decidual cells have disappeared from parts of the lateral areas (arrowed). $\times 21$. 
PLATE 1
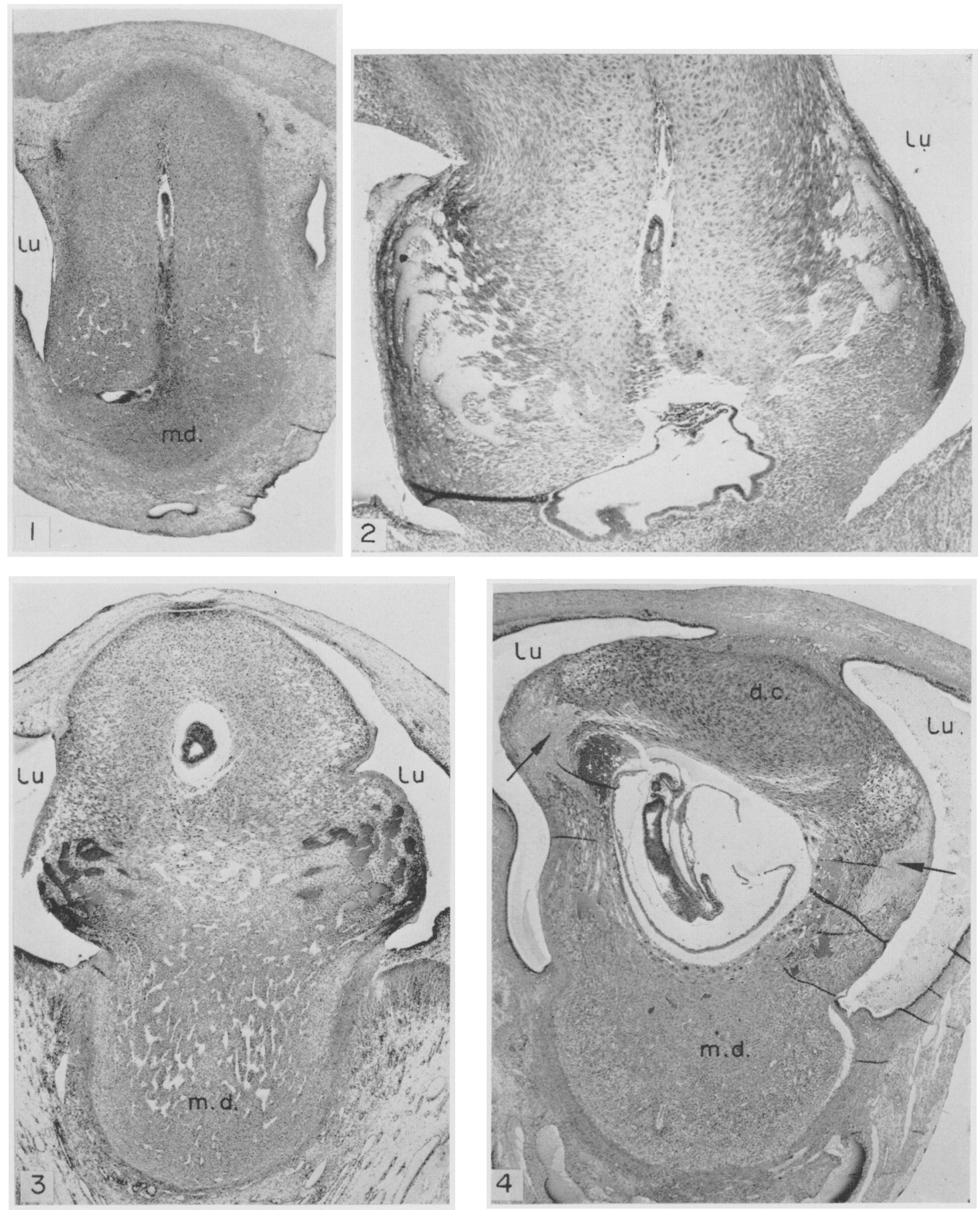

(Facing p. 184) 
PIATE?
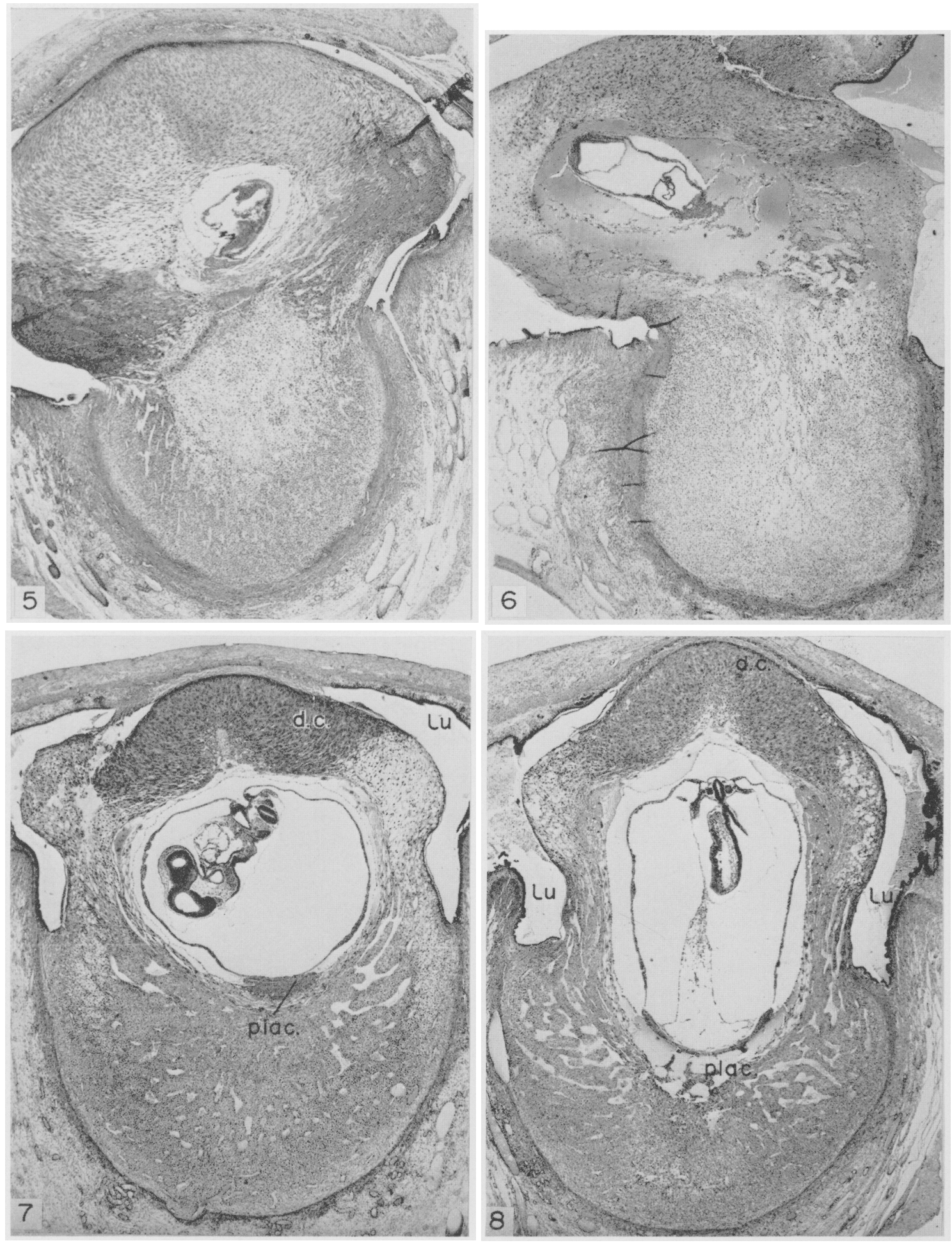

(Facing p. 185) 
polymorphs had gathered near the degenerating lateral edges. Further stages of decidual regression were seen in ovariectomized rats killed at varying times after the last progesterone injection (Pl. 1, Fig. 4, and PI. 2, Figs 5 and 6). The conceptus in Pl. 1, Fig. 4 had not lost shape and the embryo was intact and well differentiated but decidual tissue, invaded by polymorphs, had degenerated completely in lateral areas. In Pl. 2, Fig. 5, degeneration had extended to the mesometrial decidua. In eight rats ovariectomized on Days 8 and 9, given 1 or 2 $\mathrm{mg}$ of progesterone and killed at 9 or 10 days, pregnancy had terminated with massive decidual degeneration and haemorrhage (Pl. 2, Fig. 6).

To find out to what extent decidual degeneration, once begun, might be reversible, three rats, ovariectomized on Day 7, were given $2 \mathrm{mg}$ progesterone as a maintenance dose, but only $1 \mathrm{mg}$ on the next day followed by $5 \mathrm{mg}$ on Day 9 . They were killed on Day 10. The conceptuses had disappeared from one rat, except for traces of mesometrial decidua, but living ones were present in the other two in which the lateral areas of the decidua were vacuolated or degenerate and the uterine lumen contained many polymorphs. In one of them, conceptuses were small and some were non-viable, the largest weighing only $57 \mathrm{mg}$ but, in the other ovariectomized rat, average conceptus weight was $77 \mathrm{mg}$, against $97 \mathrm{mg}$ in the 10-day control, and the embryo was healthy but retarded. Cell division was continuing in the mesometrial decidua of the ovariectomized rat. In Pl. 2, Figs 7 and 8, both show vacuolation of the lateral decidua, which accompanies normal shrinkage of the antimesometrial decidua at this stage.

The same type of experiment was done on two more rats killed on Day 12; these had $2 \mathrm{mg}$ progesterone at ovariectomy on Day 7, $1 \mathrm{mg}$ on Day 8 and $5 \mathrm{mg}$ on Days 9, 10 and 11. One had viable, well differentiated embryos in conceptuses of almost normal size, but with some retardation and small areas of degeneration in the decidua capsularis and many polymorphs in the uterine lumen. The other had more retarded conceptuses, living and regressed.

Examination of sections through these and other conceptuses indicates that decidual cells which degenerate owing to progesterone deficiency are not replaced, although further degeneration may be prevented by restoration of the hormone. Mitotic activity in the decidua is waning by Day 10, but it has not ceased. Congestion, vacuolation and degeneration of the lateral areas of the

\section{PLATE 2}

Fig. 5. No. 15. Conceptus killed on Day 10, $22 \mathrm{hr}$ after ovariectomy and $1 \mathrm{mg}$ progesterone. Decidual cells show mass shrinkage and degeneration and lateral areas are congested. The embryo was still intact but differentiation had been halted. Other conceptuses from the same uterus had degenerated completely with loss of embryos. $\times 21$.

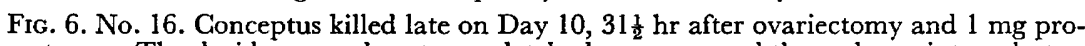
gesterone. The decidua was almost completely degenerate and the embryo, intact, but at a 9-day stage, was also near ejection. $\times 21$.

FIc. 7. No. 14. Normal 10-day conceptus showing contracted decidua capsularis, early placenta and differentiated embryo. $\times 18.5$.

FIG. 8. No. 34. Conceptus from a rat ovariectomized on Day 7 , given $2 \mathrm{mg}$, $1 \mathrm{mg}$ and $5 \mathrm{mg}$ progesterone on Days 7,8 and 9 and killed on Day 10. The conceptus, with established chorio-allantoic placenta, was viable but definitely retarded, and polymorphs in the uterine lumen near the lateral vacuolated areas indicated an earlier progesterone deficiency (Day 8$). \times 18.5$. 
decidua may not prevent continued development of the conceptus after ovariectomy, depending on the progress of degeneration and the loss of decidual tissue and blood involved, but the embryo will be retarded. Beyond a certain point, decidual degeneration accelerates rapidly if unchecked (Pl. 2, Figs 5 and 6) and pregnancy is irretrievably terminated, with cell débris and embryos passing into the uterine lumen.

The author is indebted to the Agricultural Research Council for hospitality and technical assistance.

\section{REFERENCES}

Bridgman, J. (1948) A morphological study of the development of the placenta of the rat. F. Morph. 83, 61 .

Christie, G. A. (1966) Implantation of the rat embryo: glycogen and alkaline phosphatases. $\mathcal{J}$. Reprod. Fert. 12, 279.

DeANEsLy, R. (1972) Retarded embryonic development and pregnancy termination in ovariectomized guinea-pigs: progesterone deficiency and decidual collapse. F. Reprod. Fert. 28, 241.

KREHBIEL, R. H. (1937) Cytological studies of the decidual reaction in the rat during early pregnancy and in the production of deciduomata. Physiol. Zool. 10, 212.

RothchiLD, I. \& MEYER, R. K. (1940) Maintenance of pregnancy in castrate rats by means of progesterone. Proc. Soc. exp. Biol. Med. 44, 402. 